\title{
COGNITIVE AND ONTOLOGICAL PECULIARITIES OF REALIZING UKRAINIAN PHRASEOLOGICAL CONCEPS
}

\section{Venzhynovych N. F.}

\section{INTRODUCTION}

The purpose of the article is to set forth the results of studying conceptual structure, verbalized by Ukrainian phraseological units. Its topicality is determined by the insufficient idea about the typology of phraseological concepts and lack of knowledge linked up with the peculiarities of their speech realization.

In the new paradigm of the scholarly research that was formed only a few decades ago language is considered to be an instrument of acquiring, preservation, adopting, passing information and linguistics is thought as one of the most important branches of cognitive science, which unites the whole of adjacent disciplines, aimed at learning human mind and thinking. By means of language man acquires knowledge not only about the surrounding world, but also of himself as its fragment, how language is composed, its units and categories, how it is being developed and functions ${ }^{1}$.

Among the ways of knowledge ordering, that is the models by means of which the knowledge that comes from outside is systematized in a human brain, one of the most important positions is occupied by concept, which is a unit of mental and psychical resources of our consciousness, a peculiar "information bit" of structuralized knowledge. In the thinking process concept performs a deputy function, being a representative of a great number of objects of one and the same type ${ }^{2}$.

The deputy concept function is not equal to the generalized capacity of a notion. In the traditional understanding a notion is a result of generalizing the objects of a certain class according to the totality of distinctly lined and different signs. A notion is known to be called as a final link of transition from the sensory to the rational entity: through sensation, perception and conception cognitive process forms notion as abstraction that is completely deprived of any imagery. It is this mental essence that underlies a language sign which correlated with a notion.

Concept is an integral content unit imparted with gestalt nature. Unlike a notion concept may reflect one or any several, not obligatory essential

\footnotetext{
${ }^{1}$ Кубрякова Е.С. Язык и знание. М. : Языки славянской культуры, 2004. С. 10.

2 Лихачев Д.С. Концептосфера русского языка. Известия РАН. Серия литературы и языка. 1993. Т. 52. № 1. С. 4.
} 
signs of an object. E.g., a notion of "automobile" is associated with such signs as a "means of transport", "conveyance", "wheels", "engine". At the same time, the analogical concept may include others as well: "petrol", "driving licence", "traffic police", "a breakdown". Concept does not cancel notion with itself as a rational logically meaningful essence.

One cannot equalize concept with a word meaning either. Concept is significantly broader than lexical meaning which realizes only a certain part of concept, fixed with a language sign. Neither lexical nor phraseological meaning can be identical with concept content, as concept belongs to cognitive consciousness and meaning - to the language one ${ }^{3}$. Meaning is widely known and communicatively relevant part of concept that appears as a side of a language sign in the acts of cjmmunication ${ }^{4}$. Conceps are the result of conceptualization - the most important process of human cognitive activities.

The essence of this process is in comprehension of information being closely connected with the process of the categorization.

\section{Cognitive Peculiarities}

One of the first scholars who applied the term "concept" to the phrase analysis having indicated that the substitution of the "notion" for "concept" is not arbitrary, was V. Telia. In her opinion, concept is always a structurized knowledge. It reflects not only essential signs of an object, but all those, which in a certain language community are filled with the knowledge about the essence ${ }^{5}$.

The subject-matter of modern linguistics is focused on thr solution of different aspects of cognitive phraseology, including the process of phraseologization, connected with semantic transformation of free word components, the problems of field organization of lexico-phraseological units and devices of cognitive modeling. The variants of phrase classification on the basis of methods and modes of conceptualization, cognitive aspects of their national and cultural specificity ${ }^{6}$.

Despite some publications concerning this problem, there is every reason to state that cognitive studies in phraseology make only a start.

\footnotetext{
${ }^{3}$ Алефиренко Н.Ф. Спорные проблемы семантики. Волгоград : Перемена, 1999. С. 65.

4 Стернин И.А. Когнитивная интерпретация в лингвокогнитивных исследованиях. Bonpocbl когнитивной лингвистики. Тамбов, 2004. № 1. С. 65.

5 Телия В.Н. Русская фразеология. Семантический, прагматический и лингвокультурологический аспекты. М. : Школа “Языки русской культуры”, 1996. С. 96.

${ }^{6}$ Венжинович Н.Ф. Фраземіка української літературної мови : когнітивний та лінгвокультурологічний аспекти : автореф. дис. ... д-ра філол. наук : 10.02.01 - українська мова, 2018. 43 с.; Жайворонок В. Антологія знаків української етнокультури. Словник-довідник. К. : Наукова думка, 2018.760 с.; Полюжин М.М. Об основних направлениях и процедурах лингвоконцептуального исследования. Когнитивные исследования языка. Bыn. ХХX // Материалы конгресса по когнитивной лингвистике 20-22 сентября 2017 г. Москва - Тамбов - Белгород, 2017. С. 170-173, etc.
} 
Among a wide range of problems, put forward by this direction, our attention is focused on the analysis of concepts underlying different phrases. A problem arises in ascertaining in what way and in which situations the speech of interlocutors adjusts itself to activize senses, through the medium of certain phraseological units. It is also important to reveal and describe devices of generating these senses and their national as well as cultural specificity in different languages.

Concepts are represented with different language means: words, word groups, phrases, sentences and entire fiction or scientific works. Concepts.represented with these language units are accordingly called lexical, phraseological and syntactical.

The way of concept objectification and revealing the character of its inward arrangement was offered by A. Babushkin who approached the solution of cognitive problems from exclusively linguistic position, taking into account that a semantic lexis analysis enables a researcher to receive access to the sphere of ideal entity and, thus, show the structure of the thought concealed behind its external form. The ideal essence of the concept, in his opinion, "is grasped" with a word and "is doubled" in its dictionary definition, which is reduced in a sign and is thought according to it in the shape of seme totality, forming a concrete sememe ${ }^{7}$.

If cognitive analysis focuses, first of all, on the definition of those concrete structures of knowledge, which underlie a certain language form, conceptual analysis deals with the establishment of conceptual structure, rendered by a language form and till nowadays a necessity is felt in a clearly elaborated methodology or procedure of its identification based on certain signs. While conducting conceptual analysis the task of a researcher is revalation of a "deep" conceptual structure based on the analysis of dictionary definitions, selected from different sources, which give good reason for concept differentiation ${ }^{8}$. Dictionary definitions selected from different lexicographical sources which are data medium about the object under analysis and supplemented with contextual usage in speech, may be objectified in the form of both lexemes and phrasemes - fragments of the embodied in them reflection of the word reality.

The starting subject-matter thoughts in the article is the thesis that lexis and phraseology enter the same lexico-phraseological fields ${ }^{9}$. It is based on the functional and semantic similarity characteristics that are

\footnotetext{
${ }^{7}$ Бабушкин А.П. Типы концептов в лексико-фразеологической системе языка. Воронеж : Изд-во Воронеж. гос. ун-та, 1996. С. 30.

8 Полюжин М.М. Об основних направлениях и процедурах лингвоконцептуального исследования. Когнитивные исследования языка. Bыn. XXX // Материалы конгресса по когнитивной лингвистике 20-22 сентября 2017 г. Москва - Тамбов - Белгород, 2017. С. 171.

${ }^{9}$ Попова З.Д., Стернин И.А. Общее языкознание. Воронеж : Изд-во Воронеж. гос.ун-та, 2001. С. 129.
} 
inherent in them ${ }^{10}$. The basic sign that unites phraseological and lexical meaning is the correlation of a phrase and a word with the elements of reality, basically of the same quality and, thus, the ability to have one and the same notional co-ordination ${ }^{11}$. Other linguists also repeatendly pointed out to the close word and phraseinter-connection, in particular, V. Vinigradov who wrote that in speech activities words and phrases are indefinite and movable, therefore semantic word investigations allegedly absorb the objects of phraseolgical studies ${ }^{12}$. Hence it follows that lexis and phraseology are not two isolated branches of linguistics but only two subsystems of one lexico-phraseological language system which are closely related with one another with common regularities and mutually penetrating tendencies. It means that in mental lexicon the following words and expressions stand side by side: to idle and to waist one's time, to twiddle one's thumbs; little-next to nothing, nothing to speak of, etc.

However, we remark that phrases are notionally correlated not with an endless number of lexical units, but only with that part of it which is connotatively coloured, expresses a human attitude to reality, but not only names it $^{13}$. The most convincing opinion is expressed by M. Kopylenko and Z. Popova who consider that the difference between lexical and phraseological meanings is only in the plane of expression of these meanings: a lexical meaning is expressed with a lexeme and a phraseological meaning - with a lexeme combination. It is a thought content allotted to the whole word complex not being distributed among its components. Nevertheless, it is not segmented into semes and may be equivalent to a word meaning, word combination and sentence ${ }^{14}$. Their thesis is reduced to the point of view that a phrase tends to the expression of the unique notion as it occurs in a lexeme. Therefore it is not by chance that the term phraseologization of the word came into being, bearing in mind unmotivativeness of meaning and a limited combinability among the components of a language unit - morphemes.

Concepts underlying phrases do not differ from the concepts objectificated with a word, as phraseological units with their inclination to form a nique notion realize the same cognitive structures as lexemes. It means that phraseological concepts may be differentiated on the same reasons as lexical, e.g.: to plough the sand - товкти воду в cmyni; to roll

\footnotetext{
${ }^{10}$ Сабурова Н.А. Структура фразео-семантического поля пространства. Филологические науки. 2002. № 2. С. 82 .

${ }^{11}$ Сидоренко М.И. Парадигматические отношения фразеологических единиц в современном русском языке : автореф. дис... д-ра филол. наук : 10.02.01 - русский язык. Л., 1986. С. 14.

${ }^{12}$ Виноградов В.В. Лексикология и лексикография. М. : Наука, 1977. Т. 3. С. 119.

${ }^{13}$ Проблемы фразеологической семантики. СПб : Изд-во СПб гос. ун-та, 1996. С. 11.

14 Копыленко М.М., Попова 3.Д. Очерки по общей фразеологии. Воронеж : Изд-во Воронеж. гос. ун-та, 1972. С. 26.
} 
in топеу - грошей кури не клюють; to live from hand to тоиth - жити впроголодь (concept - scenario).

From the above and similar examples one may draw a conclusion that the difference between lexical and phraseological concepts is, above all in the character of materializing them with language signs.

Of no small importance in distinguishing phraseological and lexical concepts is the thing that rational understanding of a phraseological unit is encoded. The notion of "code" penetrated into linguistics from information theory envisaging a "reiterative usage of signs, which had already an allotted primary meaning" . Representing a phraseological concept is caused by the will to reflect a certain thought expressively and figuratively and give an emotional assessment to a certain object or phenomenon.

\section{Cognitive Structure}

Phraseologically objectificated concepts are not produced by human mental forces, but are dictated to consciousness by the world ontology that finds its reflection in denotative situations, the reinterpretation of which are set figurative expressions. "Ontology" (from Greek on (ontos) the thing that exists and logos - a word, doctrine) is a philoscophical doctrine about general categories and regularities of being, comprehension of essentials of everything that exists either with mind or intuition ${ }^{16}$.

Without being deep in philosophical problems of this theory, we shall focus only how world ontology, at first, is reflected in human consciousness and is revealed in the direct meaning of language units. If we proceed from the assumption that the internal content of being is materialized in external forms of its existence, then the fact becomes evident that ontological distinctions of matter and its forms are fixed in language. This fact was investigated in detail by the precursors of cognitive interpretation of how world ontology is manifested in language grammar, its lexical and grammatical categories, the words are distributed into on the basis of certain signs. Conceptual bases of part of speech distribution is substantiality for nouns, processionality for verbs and signness for adjectives and adverbs ${ }^{17}$.

The above said about grammar is equitable as regards lexis only with the distinction that lexis provides rendering contents and grammar - the structure of the basis and framework of the forms, embodied by these contents. World ontology is reflected both in form and contents as form is

\footnotetext{
${ }^{15}$ Савченко Л.В. Феномен етнокодів духовної культури у фразеології української мови : етимологічний та етнолінгвістичний аспекти. Сімферополь : Доля, 2013. 600 с.

16 Бусел В.П.Великий тлумачний словник сучасної української мови (з дод. і допов.). К.; Ірпінь : ВТФ "Перун”, 2005. С. 844.

${ }^{17}$ Кубрякова Е.С. Части речи с когнитивной точки зрения. М. : Наука, 1997. С. 139.
} 
an external manifestation of certain contents, being the thing that fills up the form it consists of.

As a result of his observations S. Illarionov indicates the existence of the so called empirical components in the structure of a phrase meaning, which are the facts of fixing not only quality in language, but also any nonthing ideas: actions, state, space, time physical phenomena, etc. ${ }^{18}$ Thus, the researcher established a certain level of abstract categorization in phrase contents.

V. Telia also pays attention to the implication of characteristic features of an object and its signs, measure, state, action in phrase contexts, nothing that their basic mass is concentrated on the description of a person actions of their behavior, mental state and feelings, on designating of qualitative and quantitative signs in physical actions and states. ${ }^{19}$ Y. Brysina closer approaches the solution of this problem in her points of view, affirming that a phraseological corpus of any language contains the units, that express the ideas about such universal knowledge categories of a human being as time, space, property, measure, etc. ${ }^{20}$. The above said enables drawing a conclusion, that objectificating ontological world categorization some phraseological units code certain characteristics of substantial entities, others express measure, degree, dimension of anything, the third ones figuratively represent scenes of events or actions performed by anyone. However, one should pay attention to the fact that in a figurative thought ontological categories are reflected to the degree of "covering" denotative situation, which underlies a phrase and may be designed with a free word combination.

In V. Mokiyenko's opinion, modern phraseological meaning is perceived against the background of the starting direct meaning of the transformed word combination ${ }^{21}$. From this statement it follows that the direct meaning is felt in phrase semantics, which is not only its historical motivating base, but also a modern internal form.

As it is well-known, the comprehension of the internal form phenomenon originates from O. Potebnya's definition, who formulated it has the nearest etymological word meaning that way the contents are expressed. We also share his opinion, considering the internal form as a diachronic phenomenon, a track of the process by means of which a

\footnotetext{
18 Илларионов С.Ф. Различный характер образной основы в смысловой структуре лексических и фразеологических единиц. Системные отношения лексических и фразеологических единии. Курск, 1981. С. 55 .

${ }^{19}$ Телия В.Н. Русская фразеология. Семантический, прагматический и лингвокультурологический аспекты. М. : Школа “Языки русской культуры”, 1996. С. 175-176.

${ }^{20}$ Брысина Е. В. Фразеологический фрагмент языковой картины мира диалектоносителей. Слово сознание - культура : сб. науч. тр. М., 2006. С. 241.

${ }^{21}$ Мокиенко В.М. Славянская фразеология. М. : Высшая школа, 1989. С. 157.
} 
phraseological unit was formed in language. Unlike the internal form of direct nomination inherent word signs, the internal form of signs of the secondary nomination to which a phrase belongs is considerably more informative as it projects the properties and signs of elements of the denotative situation, the relations among them, turning and concretizes subjective thoughts focused in it. That is why a great number of linguists and culturologists study the origin of set phrases, as correctly interpreted starting images of phrases enable to draw nearer to the revelation of objective "language world model", realize the history of concept formation, that nowadays native speakers operate.

Approximately the same thought is expressed by V. Uzhchenko asserting that a phrase explicitly or implicitly, at the level of etymological researchers - preserves its historical and semantic nature, the observation of which has been performed from the origin if necessity arises till the variable prototype a phraseological unit that is considered as generalized, hyperword free syntactical expression of the element of ethnoculture, given as denotation ${ }^{22}$.

The main role in rational thinking is played by the processes of transference of knowledge (information) from one (primary) structured branches of knowledge to others. New knowledge is based on the previous experience, at this some of its aspects are preserved in a new quality. Thinking over like that, V. Telia "poins out that idioms, as a general rule, transfer" certain signs from the initial word combination for them ${ }^{23}$.

Without underestimating scholarly significance of the above mentioned thoughts of well-known linguists we shall dwell upon the monograph by L. Kovayova in detail, in which the author deals with the analysis of phraseologization as a particular cognitive process. Methodological basis of this research is a semantically oriented conception, familiar in phraseology, by M. Kopylenko and Z. Popova who convincingly proved that different phrase combinations (under phrase combinations the scholars bear in mind all the types of lexeme combinations from "free" to idioms) are not equal as far as idiomaticity is concerned and differ depending on the type of sememes, which are marked by lexemes forming a part of this combination. The higher idiomaticity of phrase combination, the more "knitting together" among its components and, thus, the stronger the tendency of phrase combination to the expression of a unique notion. The researchers consider different

\footnotetext{
${ }^{22}$ Ужченко В.Д. Культурно-национальный компонент в украинских фразеологических единицах. Слово во времени и пространстве: К 60-летию проф. В.М. Мокиенко. СПб : Фолио - Пресс, 2000. C. $186-187$.

${ }^{23}$ Телия В.Н. Русская фразеология. Семантический, прагматический и лингвокультурологический аспекты. М. : Школа “Языки русской культуры”, 1996. С. 85.
} 
combinatorial analysis of denotative and connotative sememes, which lead to the idiomatic displacement within one and the same lexeme combination in the endeavour of the latter to express a phraseologically bound meaning. Far the analysis of different types of expressions M. Kopylenko and Z. Popova use the following two letter marks: D - denotative, "free" meaning, $\mathrm{K}$ - connotative, phraseological meaning and single out 5 varieties of sememes, expressed by a lexeme. According to the symbols, suggested by the authors, they are: $\mathrm{D}_{1}, \mathrm{D}_{2}, \mathrm{D}_{3}, \mathrm{~K}_{1}, \mathrm{~K}_{2}, \mathrm{~K}_{3}$. Sememe $\mathrm{D}_{1}$ corresponds to the direct nominative meaning and is recognized in a lexeme outside the context, e.g., a flover blooms, the children play; sememe $\mathrm{K}_{1}$ is a connotatively marked idiomatic displacement but is "transparent" owing to its motivation, e.g., It is enough to make a cat laugh, as plain as the nose on a man's face. All the phrase combinations are arrauged in the form of the ascending ladder from $D_{1} D_{1}$ (free combination of denotative sememes that corresponds to the direct nominative meaning) to $\mathrm{K}_{3} \mathrm{~K}_{3}$ (the totality of the connotative sememes which are semantically unique expressions according to the plan of their contexts ${ }^{24}$. The types of phrase combinations from $\mathrm{K}_{1} \mathrm{~K}_{1}$ to $\mathrm{K}_{3} \mathrm{~K}_{3}$, in their opinion, are phrasemes ${ }^{25}$.

In Kovalyova's publication the development of phraseological meaning from cognitive point of view is under consideration, and universal regularities of cognitive processes of phraseologization are revealed. On the basis of semantic changes that occur during the development of phrases $\mathrm{K}_{1} \mathrm{~K}_{1}$ from free word combinations the researcher reveals cognitive processes that link the meanings $\mathrm{D}_{1} \mathrm{D}_{1}$ with the meaning of $\mathrm{K}_{1} \mathrm{~K}_{1}{ }^{26}$.

The way of verbalization of denotative situations, in L. Kovalyova's opinion, is a free combinations of denotative sememes $D_{1} D_{1}$. This free lexeme combination is a prototype, the basis of the process of phrase formation. For the illustration the researcher observes the development of the denotative situation of the Russian phrase сматьввать удочки into connotative having the main plan 'a hasty departure from the river after the end of fishing' As a result of thinking process that are based on associative links a metaphoric transference of selected thinking signs (the end of fishing and hasty departure) on any other action, connected with the necessity of finishing a hasty departure, which gives a set expression $\mathrm{K}_{1} \mathrm{~K}_{1}$. It preserves a motivating sign "hastily finish something and leave",27.

\footnotetext{
${ }^{24}$ Копыленко М.М., Попова З.Д. Очерки по общей фразеологии. Воронеж : Изд-во Воронеж. гос. ун-та, 1972. С. 77.

${ }^{25}$ ibidem, C. 33.

${ }^{26}$ Ковалева Л.В. Фразеологизация как когнитивный процесс. Воронеж : Изд-во Воронеж. ун-та, 2004. $184 \mathrm{c}$.

${ }^{27}$ ibidem 2004, C. 27.
} 
Though the author considers the process of phraseologization from the cognitive point of her research does not deal with the character of phraseological concepts of different types. Neither does it reveal the ontological nature of its factors that cause them. Meanwhile it is the difference in denotative situations that leads to the concept that don't coincide with their arrangement. This point of view is confirmed by the principle of iconicity the designated sign to the object which is designated. It is easier to preserve, elaborate and transfer the encoded experience if the code is maximally isomorphic to this experience ${ }^{28}$.

Indisputable is the fact that the history of arising phraseological concept-pictures testifies to the reflection of some substance and its signs in denotative phrase meanings $\left(\mathrm{D}_{1} \mathrm{D}_{1}\right)$ as well as its signs, that "paint" mental images. E. g., Siamese twins, who are extremely rare and medical operations to separate them is often very dangerous. They are called this because of a famous pair of twins in the XIX ${ }^{\text {th }}$ century who were born in Siam (Thailand). Nowadays the expression "Siamese twins" is used for the designation of those people who are inseparable friends.

A phrase to use a sledge-hammer to crack a mut means "to exaggerate efforts" in doing something (concept-scheme).

The Square of Dignity means the struggle of Ukraine's population against the abuse of power.

To beat the air means to do useless things (concept-scenario).

From the above said it has become evident that the signs of substantial character are fixed with concept-pictures, signs of measure - concept schemes, the description of the state - concept - frames and signs of motion and process - concept - scenarios as the semantic structure, underlying reinterpretation.

Therefore concepts are not produced "exclusively with mind" but are dictated to the consciousness by the ontology of the world, reflected in denotative situations the interpretation of which are set figurative expressions.

Solving the problems of world ontology reflection, we consider it necessary to note that the above mentioned concepts with inherent in them specificity bear information about the state of the matter both in real and imaginary world. Therefore it turns out that categorical characteristics of action, state, space, time, properties of an object, etc. may be both such that are available in the following concepts - pictures, schemes, frames and scenarios and those when phraseologically named realia are under consideration, which are in fact lacking in the world around, e.g. to come

\footnotetext{
${ }^{28}$ Алефиренко Н.Ф. Поэтическая энергия слова. Синергетика языка, сознания и культуры. М. : ACADEMIA, 2002. C. 68.
} 
off with a whole skin, to save one's bacon, to teach the dog to bark, bad news has wings, care killed the cat, curses like chickens come home to roost, etc. Here one should add, that phrases formed on the basis of "unreal realia" are a peculiar code with which facts of the real world are "encoded". They always reveal themselves as the most vivid and expressive units of the phraseological stock of any language.

Nosing after the history of phraseological concept formation - pictures, schemes, frames and scenarios convinces that phrases, representing cognitive structures under investigation are not unique. The analysis carried out has shown the availability whole classes of phraseological units, which realized the described concepts. It means that a great number of phrases have reason to be considered concept representatives - mental pictures, schemes, frames and scenarios correspondingly. Phraseological units, verbalizing above mentioned concepts differ from one another according to their contents, though there is something in common that draws them closer and directs to grouping, depending on the fact what cognitive structures they represent, that is what type of a phraseological concept is objectificated. Therefore "family similarity" here may be not so much external as internal, similarly to the fact how members of one and the same family may be alike to one another not only according to external signs but also features of character and inclinations.

Regarding concepts, which are rendered by means of phraseological units the use of corresponding dictionary definitions is sometimes quite insufficient. The conceptual contents of a phrase is "read-out" not only according to its dictionary definition, but also as a result of synthesis of sense, rendered by it, and the internal form of a phraseological units. This is the specificity of phraseological concept. Let us dwell upon each of them.

\section{Mental Picture. Scheme}

The semes in semantic structure of language means, which enable "catching" concept-picture are called figurative as they reflect, above all, in "a picture way" the unfolded idea both about the objects of the world around and the world anybody's imaginations, e.g.,: a bit of blood, blood is thicker than water, blood and thunder, new blood, etc.

Phraseological dictionaries of Ukrainian certain a great number of set expressions the semantic characters of which enable judging about the nature of cognitive structures that belong to concept-structures. They may be phrases that objectificate mental images correlating with a human appearace. It is known that a great number of phrases are anthropomorphically oriented. According to Yu. Stepanov's just remark 
linguistics will always be a branch of knowledge about language in a human being and about a person in a language.

Among the phrases, which allegorically show a person looks like, a significant position is occupied by those, that form images, correlating with zoomorphisms. They are: a black hen lays a white egg - 'appearances are deceptive'; a cat in gloves catches no mice - 'everything is done with applying efforts'; a cock is variant on his own dunghill - 'no heroism in doing anything'; a curst cow has short horns - 'those who are cursed can do very little'; a fly in the ointment - 'something miserable that has spoiled a great deal of something'; a fox is not take twice in the same snare - 'it is impossible to deceive old and experienced persons'; a good dog deserves a good bone - 'a person is rewarded according to his or her deserts'.

Zoomorphic phrases that realize a concept-picture, also include: a black cat, an ugly duckling, a sleepy fly, etc. There are also phrases that correlate not only with zoomorphisms but also with colour characteristics of an object. Colour is one of the most vivid signs of a particular person, thing or phenomenon which are sensuously perceived, an important element of objective reality, one of the forms of being, underlying world cognition.

The ability of a person to see a colour association with an already known object is the result of cognitive processes in which comprehension and structuring of new images occurs, e.g.: men (gentlemen, boys) in blue 'policemen'; a white crow - 'rare phenomenon'; a yellow dog 'a cowardly, foul man, a contemptuous person'; a brown shirt - 'a nazist'; a red cock - 'a fire'.

Figurative semes are able to reflect objects, that correlate with folklore, mythological and biblical plots, e.g.: water nymph - 'a mermade'; be in deep waters - 'to be in difficult position'; the Alpha and Omega 'the beginning and end, the most essential thing'; an angel of light 'a person that is dear and beloved by everyone'; as old as Methuselah 'every old, old as Methuselah'.

The given examples testify that the contents of phraseological units, realizing concept-pictures may be very diverse, however in this diversity one and the same type of concept is nosed after. It is due to this reason that the above mentioned phrases are considered as set figurative expressions having certain similarity with one another. Such phrases call visible ideals in human consciousness, "picture" images drawn as a result of ocular perception. As it is well-known, eyesight is one of the main channels of coming information about the world.

Concept-scheme as a type of mental structure is an exceptionally rare phenomenon in phraseology. Only those phrases, which verbalize 
extremely simplified models (from which their figurative beginning has been emasculated) may scheme cognitive structures in the consciousness of a native speaker, that correlate with concept-schemes. To phraseological units, which objectivate concept-schemes, one may conditionally enough refer to a lanky fellow, that is when people speak of a person who is exceedingly high. Only the idea of vertical projection in space, that correlates with the concept-scheme remains in the consciousness of Ukrainian speakers.

The category of space form is organically built in the coceptosphere of "space". The geometrical nominations of the type "the quadrature of a circle" occupy central place in the lexico-semantic field of "form". There is a seme "a geometrical figure in space" in the meaning of this phraseological unit when Ukrainians speak about an insoluble task, about something, which is absolutely impossible and inaccessible.

\section{Schematic Picture. Frame. Scenario}

A particular cognitive structure is singled out between a conceptpicture and a concept-scheme. On the one hand, it underlies set expressions the meaning of which contain signs, characterising a concept-scheme, on the other one, such a cognitive structure that is associated with figurative semes, cannot be exclusively equated with a scheme, being a summary as a certain synthesis of a scheme and a picture.

An expression a way of life as a phraseological unit is not yet fixed in dictionaries however, it is widely used in Modern Ukrainian. A way of life is perceived as a certain way (according to an imaginery line, leading upwards downstairs, to the right, to the left) from birth to death of a human being. A way of life is also a natural furrow of a certain extent on a human palm, with which one may define beforehand the duration of his or her life. The idea of vertical projection is also nosed after in phrases of the type Babel pandemonium, Lombardy poplar, etc.

A scheme in the form of a certain horizontal projection is revealed in the plane of contents of the phrase at (to) the world's end, however one may imagine a feature according to which the world becomes invisible, is not perceived with eyes, that is the place where it is ended. Its meaning is very far; a secluded corner - 'a remote, out-of-the way place, which is rarely populated'.

In association with a phrase secluded conner, the taiga corner come into being, which is not yet fixed in dictionaries but already fixed in conscious of people who populate taiga. See also: at stone's throw close at hand, far and wide, to have (smth.) at one's fingers' ends. 
The scheme of measure is fixed in the expressions it makes a cat laugh, nothing to speak of, a drop in a bucket, pocket money, etc.

In Ukrainian there are phrases that objective a concept-schematic picture, the components of which are geometrical nominations, which cause figurative images in consciousness, e.g.: a vicious circle, lover's triangle, pyramid of power, etc.

According to the definition a triangle is a geometrical figure that is limited with three direct lines that interest and form three integral corners and any object $f$ the same form. The situation that is designated with the expression lover's triangle also provides the presence of three participants. Therefore there is reason for the assertion, that while perceiving of a figurative meaning of an expression a native speaker of Ukrainian compares mental measure with a triangle and appeals to the knowledge about its properties. The properties of a circle, its "locked vision" are reflected in the meaning of the expression a vicious circle - a combination of events from which it is difficult to find any exit.

Thus, a scheme (a schematic picture) as a type of a phraseological concept may be represented in different ways. Phraseological conceptschematic pictures are materialized with phrases, in the meaning of which measuring parameters, vector representations and geometric configurations of objects, associated with figurative images, are reflected. However, all the available alternatives are only variants of the scheme-invariant which serves as the basis of the above mentioned phrases.

Concept-frames are represented with phrases, the meaning of which correlate with a state, a certain state of affairs. They are also pictures but with volumetric ("golographic") contents.

The examples of concept-frames, that are verbally explicated with phrases, are the following phraseological units: martial law, morale, state of health, state of siege, weather conditions, in a bad state, neglected state, etc., containing the same "state of affairs" in their plane of contents. The phrases of this group are imported with a number of common features, among which one may single out the description of a static situation, deprived of visible and perceptible changes as well as characteristic of arisen circumstances, e.g.: Augean stables - 'according to ancient Greek stories, the very dirty buildings where a king named Augean kept thousands of cattle'; the Promised Land - 'in the Old Testament of the Bible the Land of Canaan, which God promised to give to the Israelites'.

A concept-frame verbalized phrases, containing a seme "volumetric vision of place", e.g.: in the field of battle, mass media sphere; sphere of action, field of vision, free economic zone, disaster area, etc. In this case a phraseological frame as a specific structure of knowledge representing that 
implies a complex, volumetric vision of realia gives an integral idea about the place with characteristic for it community of any signs and conditions.

Concept-frames also represent the following phrases: on a death bed, by the road, by the bank, beyond the limits of understanding, beyond the borders of the country, on the edge of a knife, by a thread, etc., containing a seme "an extreme state". In this case a concept-frame, implying a complex situation that embodies everything that is typical and essential for a limiting state, beyond which there may be transition to a new state, e.g., within a hairbreadth of smth. - in an extreme dangerous state (close to death, ruin, catastrophy, etc., that is close to any other dangerous state).

Thus, versatile phraseological concept-frames are objectivated with phrases containing the following semes: "a state of affairs", "the volumetric vision of the place", "an extreme state", having a unique, combining them cognitive factor.

"Family similarity" is perceived in the sense implication of a number phraseological units, which are inherent in the semes of motion, the development of events, reflecting at this the following: a) relocation (changing places), e.g., to get out of bed on the wrong side, to walk in step, to tread on smb's corns (toes), to trip one up, etc.; b) procedural action, e.g. to go to extremes, to play at blind man's buff, to cover up one's traces (tracks), to put out a feeler, to drop a kind word in favour, etc.; c) the influence on the object, e.g.: to have effect (on), to bring trouble, to face down at smb's feet, to act craftily, to play the fool, make a fool of oneself, to turn up one's nose, etc.

\section{CONCLUSIONS}

Considering questions concerning classification of concepts in phrases we draw a conclusion that they significantly vary within the limits of certain sense domains. Even within one and the same domain they are different though in each of them unique reasons, inherent in all the members of a certain category, are felt. For the phrases that represent concept-pictures they are image semes, for those that verbalize schemes - semes of measures and spatial parameters (upstairs - downstairs, to the left - to the right), for the phrases, which represent schematic pictures - semes of measure and spatial parameters, associated with the visual image about correlative with them objects of reality. For the phrases that materialize concept-frames they are semes of state a state of affairs, for the phrases that objectivate conceptscenarios - semes of action and motion. Thus, there is every reason for the conclusion that human consciousness there are imagery senses of different conceptual arrangement, which are ready for objectification in speech at the availabity of an adequate intention. 
The structure of knowledge presentation in a human head reflects the way how human mind or intuition comprehends essentials of everything available in the world around. Certain signs of substantial essences are fixed with concept-pictures, different measurable characteristics - with concept-schemes (including adjacent cases, that draw nearer a picture and a scheme).

State and state of affairs are embodied in concept-frames and scenes of events or actions, executed actions by anyone - in scenarios.

In language consciousness categorical characteristics of action, state, space, time, properties of a subject, etc. are reflected not directly but through the medium of language units and this means, that through the phrase meaning correlative with objects of both real and imaginary worlds. Unequal denotative situations as far as their nature is concerned lead to the formation of different types of phraseological concepts as the semantic structure of phrases inherits and incorporates the features of initial mental structure, underlying the basis of reinterpretation.

The phraseological material analyzed in the article enabled answering a question how the prerequisites are conceived in human consciousness for sense objectification, expressed by set expressions in what cases it occurs and, at last, with what the system of figurative thinking is defined. The analysis was based on the comprehension that concepts as ideal formations are studied by linguists at the time when they turn out to be "caught" by the meaning of language signs, the expression means of which are phraseological concepts in the form of mental pictures, schemes, frames and scenarios.

\section{SUMMARY}

The article deals with the expounding the results of studying conceptual structures and elucidating how images (senses) come into being, the plane of the expression of which are language units, verbalized with the phraseological stock of the Ukrainian language. Its relevance is stipulated that the studies in the field of typology of phraseological concepts are insufficient and lack of investigations concerning the revelation and description of the peculiarities of their language realization.

The author proceeds from the assumption that denotative situations underlie the basis of figurative set expressions, however, in the meaning of word combinations, designating them, denotative semes, in time, are changed into connotative. Ontological essences are revealed in the following denotative situations: categories of an object and its signs, measure, state and process. The author comes to a conclusion, that these parameters are reflected in concepts of different types, they are 
incorporated in the meaning of language signs under reinterpretation. Another conclusion is drawn that the sphere of conceptual knowledge enables penetrating into specific mental processes covert out of immediate observation. However, not all the concepts, objectificated with phraseological means, may be included in pictures, schemes, frames and scenarios. Unanalysed types of concepts, materialized with phrases, still expect their first investigators.

\section{REFERENCES}

1. Алефиренко Н.Ф. Спорные проблемы семантики. Волгоград: Перемена, 1999. 274 с.

2. Алефиренко Н.Ф. Поэтическая энергия слова. Синергетика языка, сознания и культуры. М.: ACADEMIA, 2002. 391 с.

3. Бабушкин А.П. Типы концептов в лексико-фразеологической системе языка. Воронеж: Изд-во Воронеж. гос. ун-та, 1996. 104 с.

4. Брысина Е. В. Фразеологический фрагмент языковой картины мира диалектоносителей. Слово - сознание - культура: сб. науч. тр. М., 2006. С. 240-248.

5. Бусел В.П.Великий тлумачний словник сучасної української мови (з дод. і допов.). К.; Ірпінь: ВТФ “Перун”, 2005. 1728 с.

6. Венжинович Н.Ф. Фраземіка української літературної мови: когнітивний та лінгвокультурологічний аспекти: автореф. дис. ... д-ра філол. наук: 10.02.01 - українська мова, 2018. 43 с.

7. Виноградов В.В. Лексикология и лексикография. М.: Наука, 1977. Т. 3. 319 c.

8. Жайворонок В. Антологія знаків української етнокультури. Словник-довідник. К.: Наукова думка, 2018. 760 с.

9. Илларионов С.Ф. Различный характер образной основы в смысловой структуре лексических и фразеологических единиц. Системные отношения лексических и фразеологических единиц. Курск, 1981. С. 55-62.

10. Ковалева Л.В. Фразеологизация как когнитивный процесс. Воронеж: Изд-во Воронеж. ун-та, 2004. 184 с.

11. Копыленко М.М., Попова 3.Д. Очерки по общей фразеологии. Воронеж: Изд-во Воронеж. гос. ун-та, 1972. 121 с.

12. Кубрякова Е.С. Части речи с когнитивной точки зрения. М.: Наука, 1997. 330 с.

13. Кубрякова Е.С. Язык и знание. М.: Языки славянской культуры, 2004. 560 с.

14. Лихачев Д.С. Концептосфера русского языка. Известия РАН. Серия литературы и языка. 1993. Т. 52. № 1. С. 3-9. 
15. Мокиенко В.М. Славянская фразеология. М.: Высшая школа, 1989. $187 \mathrm{c}$.

16. Полюжин М.М. Об основних направлениях и процедурах лингвоконцептуального исследования. Когнитивные исследования языка. Bbı. $X X X / /$ Материалы конгресса по когнитивной лингвистике 20-22 сентября 2017 г. Москва - Тамбов - Белгород, 2017. С. 170-173.

17. Попова З.Д., Стернин И.А. Общее языкознание. Воронеж: Изд-во Воронеж. гос.ун-та, 2001. 191 с.

18. Проблемы фразеологической семантики. СПб: Изд-во СПб гос. ун-та, 1996. $172 \mathrm{c.}$

19. Сабурова Н.А. Структура фразео-семантического поля пространства. Филологические науки. 2002. № 2. С. 81-87.

20. Савченко Л.В. Феномен етнокодів духовної культури у фразеології української мови: етимологічний та етнолінгвістичний аспекти. Сімферополь: Доля, 2013. 600 с.

21. Сидоренко М.И. Парадигматические отношения фразеологических единиц в современном русском языке: автореф.дис.... д-ра филол. наук: 10.02.01 - русский язык. Л., 1986. 18 с.

22. Стернин И.А. Когнитивная интерпретация в лингвокогнитивных исследованиях. Вопросы когнитивной лингвистики. Тамбов, 2004. № 1. С. 65-70.

23. Телия В.Н. Русская фразеология. Семантический, прагматический и лингвокультурологический аспекты. М.: Школа “Языки русской культуры”, 1996. 284 с.

24. Ужченко В.Д. Культурно-национальный компонент в украинских фразеологических единицах. Слово во времени $и$ пространстве: К 60-летию проф. В.М. Мокиенко. СПб: Фолио Пресс, 2000. С. 186-195.

\section{Information about the author:} Venzhynovych N. F., Doctor of Philological Sciences, Professor at the Ukrainian Language Department, Uzhhorod National University 14, Universytetska str., Uzhhorod, 88017, Ukraine 